\title{
Commentary
}

\section{The between Now and Then of Lung Cancer Chemotherapy and Immunotherapy}

\author{
Roberta Visconti ${ }^{1, *}$ (D), Francesco Morra ${ }^{1}$, Gianluca Guggino ${ }^{2}$ and Angela Celetti ${ }^{1, *}$ \\ 1 Institute for the Experimental Endocrinology and Oncology "G. Salvatore”, \\ Italian National Council of Research, via S. Pansini 5, 80131 Napoli, Italy; francesco.morra@unina.it \\ 2 Thoracic Surgery Unit, Antonio Cardarelli Hospital, via A. Cardarelli 9, 80131 Napoli, Italy; \\ gianlucaguggino@gmail.com \\ * $\quad$ Correspondence: r.visconti@ieos.cnr.it (R.V.); a.celetti@ieos.cnr.it (A.C.); Tel.: +39-081-229-0142 (R.V. \& A.C.)
}

Received: 5 June 2017; Accepted: 25 June 2017; Published: 27 June 2017

\begin{abstract}
Lung cancer is the most common cancer worldwide. Disappointingly, despite great effort in encouraging screening or, at least, a close surveillance of high-risk individuals, most of lung cancers are diagnosed when already surgically unresectable because of local advancement or metastasis. In these cases, the treatment of choice is chemotherapy, alone or in combination with radiotherapy. Here, we will briefly review the most successful and recent advances in the identification of novel lung cancer genetic lesions and in the development of new drugs specifically targeting them. However, lung cancer is still the leading cause of cancer-related mortality also because, despite impressive initial responses, the patients often develop resistance to novel target therapies after a few months of treatment. Thus, it is literally vital to continue the search for new therapeutic options. So, here, on the basis of our recent findings on the role of the tumor suppressor CCDC6 protein in lung tumorigenesis, we will also discuss novel therapeutic approaches we envision for lung cancer.
\end{abstract}

Keywords: lung neoplasms; antineoplastic agents; biomarkers; poly(ADP-ribose) polymerase inhibitors; CCDC6

\section{Introduction}

Lung cancer is the most common cancer worldwide and its incidence, while decreasing in some countries—such as the United States—is expected to further rise in others-such as China-where there has been a dramatic increase in smoking during the past decades [1]. When feasible, surgical resection remains the treatment of choice for early stage, localized tumors and can be curative [2]. After surgical resection, adjuvant chemotherapy is prescribed to lower the risk of recurrence in patients with lymph node involvement [3,4]. However, despite great effort in encouraging smoking cessation, screening in high risk individuals, and prompt diagnostic procedures in symptomatic patients, most lung cancers are discovered when already locally advanced. In this case, in appropriately selected patients, neoadjuvant chemoradiotherapy can be used to reduce the tumor mass and achieve surgical resectability [3,5]. Otherwise, patients classified as having unresectable, locally advanced lung cancer are treated with concurrent chemoradiotherapy [3]. Chemotherapy is also the only palliative, systemic treatment for metastatic tumors [3]. Finally, chemotherapy is the treatment of choice for patients that, regardless of tumor stage, are not eligible for lung resection because of their respiratory and/or general status [3]. Thus, overall, more than $80 \%$ of newly diagnosed lung cancer patients receive chemotherapy, alone or in combination with radiotherapy.

Despite recent great advances in the identification of novel targetable genetic lesions and in the development of new drugs, lung cancer is still the leading cause of cancer-related mortality: thus, one of the major human killers with a disappointing five-year survival rate of $15 \%$ [1]. It is, therefore, literally vital to search for new drugs or to improve the current treatment protocols to increase efficacy, 
overcome resistance, and reduce side effects. Here we will briefly review the most successful and recent advances in the therapy of lung cancer, especially of non-small-cell lung cancers (NSCLCs). Moreover, we will discuss new therapeutic options we suggest on the basis of our recent findings on the role of the tumor suppressor CCDC6 protein in lung cancer.

\section{Discussion}

\subsection{Latest FDA-Approved Therapeutics for NSCLCS}

NSCLCs, that mainly comprise adenocarcinomas and squamous cell carcinomas (SCCs), account for more than $85 \%$ of all lung cancers [6]. The combination of carboplatin and paclitaxel has long been the most common first-line therapeutic regimen prescribed for NSCLCs; however, in the last few years, NSCLC treatment has been dramatically changed by the FDA approval of many new target therapies (Table 1).

Table 1. Target therapy for NSCLCs.

\begin{tabular}{|c|c|c|}
\hline Target Protein & FDA Approved Drug & Relevant Clinical Trial Results \\
\hline \multicolumn{3}{|r|}{ First Line Therapy } \\
\hline ALK-1 ROS1 & Crizotinib [7-9] & $\begin{array}{l}\text { In ALK-1 positive tumors, PFS was significantly longer with crizotinib } \\
\text { than with chemotherapy (median } 10.9 \text { Mos vs. } 7.0 \text { Mos; HR for } \\
\text { progression or death with crizotinib, } 0.45 ; 95 \% \text { CI, } 0.35-0.60 ; p<0.001) \text {. } \\
\text { In ROS1 positive tumors, ORR was } 72 \%(95 \% \text { CI, } 58-84) \text {, with } 3 \text { complete } \\
\text { and } 33 \text { partial responses. Median duration of response was } 17.6 \text { Mos } \\
\text { (95\% CI, 14.5-NR). }\end{array}$ \\
\hline EGFR HER2 & Afatinib $[8,10]$ & $\begin{array}{l}\text { Median OS 28.2 Mos (95\% CI, 24.6-33.6) in the afatinib group and } \\
28.2 \text { Mos }(20.7-33.2) \text { in the pemetrexed-cisplatin group (HR 0.88; } 95 \% \mathrm{CI} \text {, } \\
0.66-1.17 ; p=0.39 \text { ). Median OS } 23.1 \text { Mos }(95 \% \text { CI, } 20.4-27.3) \text { in the } \\
\text { afatinib group and } 23.5 \text { Mos }(18.0-25.6) \text { in the gemcitabine-cisplatin } \\
\text { group (HR } 0.93 ; 95 \% \text { CI, } 0.72-1.22 ; p=0.61 \text { ). }\end{array}$ \\
\hline VEGF & Bevacizumab $[8,11]$ & $\begin{array}{l}\text { Compared with chemotherapy alone, bevacizumab significantly } \\
\text { prolonged OS (HR 0.90; } 95 \% \text { CI, } 0.81-0.99 ; p=0.03) \text {, and PFS } \\
(0.72 ; 95 \% \text { CI, } 0.66-0.79 ; p<0.001)\end{array}$ \\
\hline \multicolumn{3}{|r|}{ Second Line Therapy } \\
\hline ALK-1 & $\begin{array}{l}\text { Ceritinib }[8,12] \\
\text { Alectinib }[8,13] \\
\text { Brigatinib }[8,14]\end{array}$ & $\begin{array}{l}\text { For ceritinib, median PFS was } 18.4 \text { Mos }(95 \% \text { CI, } 11.1 \text {-non-estimable) in } \\
\text { ALK inhibitor-naive patients and } 6.9 \text { Mos in ALK inhibitor-pretreated } \\
\text { patients. For alectinib, median PFS was } 8.9 \text { Mos ( } 95 \% \text { CI, } 5.6-11.3) \text {. } \\
\text { For brigatinib, median PFS was } 9.2 \text { Mos }(95 \% \text { CI, } 7.4-15.6) \text { and } 12.9 \text { Mos } \\
\text { ( } 95 \% \text { CI, 11.1-NR) depending on the dosage. }\end{array}$ \\
\hline EGFR (T790M) & Osimertinib $[8,15]$ & $\begin{array}{l}\text { Median PFS was 9.6 Mos (95\% CI, 8.3-NR) in EGFR T790M-positive } \\
\text { patients and 2.8 Mos (95\% CI, 2.1-4.3) in EGFR T790M-negative patients. }\end{array}$ \\
\hline VEGFR2 & Ramucirumab $[8,16]$ & $\begin{array}{l}\text { Median PFS was } 4.5 \text { Mos for the ramucirumab group compared with } \\
\text { 3.0 Mos for the control group }(p<0.0001) \text {. }\end{array}$ \\
\hline
\end{tabular}

\footnotetext{
Abbreviations: $\mathrm{PFS}=$ progression free survival; $\mathrm{Mos}=$ months; $\mathrm{HR}=$ hazard ratio; $\mathrm{CI}=$ confidence interval;
} $\mathrm{ORR}=$ objective response rate; $\mathrm{NR}=$ not reached; $\mathrm{OS}=$ overall survival.

About $5 \%$ of NSCLCs express the EML4-ALK fusion oncogenic protein in which the ALK kinase is constitutively active [17]. For ALK-positive NSCLC metastatic patients, the FDA has approved crizotinib—a small tyrosine kinase inhibitor-as the first line of therapy $[7,8]$. Last year, the FDA expanded crizotinib use also to the $1-2 \%$ of NSCLC patients with ROS1 rearrangements $[8,9,18]$. In both cases, however, despite an impressive initial response, patients develop a resistance after a few months of treatment. For ALK positive patients, which relapse after crizotinib treatment, there are three second-generation ALK inhibitors available: ceritinib, alectinib, and the very recently approved brigatinib [8,12-14].

Most of the recent FDA approved drugs for NSCLC therapy target the Epidermal Growth Factor (EGF) pathway. Afatinib is a second-generation irreversible inhibitor of both EGF receptor 
(EGFR) and epidermal growth factor receptor 2 (HER2). It is FDA-approved as frontline therapy in metastatic NSCLC patients with documented activating EGFR mutations and it is now preferred to the first-generation EGFR inhibitors erlotinib and gefinitib, as their long-term efficacy is limited by development of resistance $[8,10]$. The most common resistance mechanism is the development of a secondary mutation in EGFR, T790M [19]. Recently, after a very successful clinical trial, the FDA has approved osimertinib-a third generation selective EGFR T790M inhibitor-for patients that have progressed after therapy with first or second generation EGFR inhibitors [8,15]. Of note, in contrast to what established for advanced colorectal cancer, in NSCLC, at present, the evidence that K-Ras mutations predict a lack of benefit from EGFR-targeting therapy is not strong enough to impose K-Ras status investigation before starting treatment [20].

Another target in NSCLC therapy is the tumor angiogenetic Vascular Endothelial Growth Factor (VEGF) pathway. Ramucirumab, a monoclonal antibody that works as a receptor antagonist blocking the binding of VEGF to VEGFR2, is approved as second-line therapy in combination with docetaxel for EGFR- and ALK-negative patients with disease progression on or after platinum-based chemotherapy $[8,16]$. The monoclonal antibody bevacizumab, that binds to soluble VEGF preventing receptor binding, has been approved, in combination with platinum-based chemotherapy, for first-line treatment of unresectable, locally advanced, recurrent, or metastatic non-squamous NSCLCs $[8,11]$. The SCCs are excluded because of a higher risk of serious, life-threating hemorrhagic adverse events [21]. Moreover, unlike adenocarcinomas, lung SCCs rarely harbor EGFR and ALK mutations, thus, until very recently, there has not been significant improvement in their treatment [22]. Now, however, immunotherapies targeting the programmed cell-death-1 receptor (PD-1) or its ligand, PD-L1, have expanded the treatment options (Table 2). Physiologically, PD-1 is expressed on regulatory and cytotoxic activated T cells. Binding of PD-L1 to its receptor inactivates the T cells, a key mechanism to limit immune responses [23]. PD-1 is highly expressed on many tumor-infiltrating lymphocytes but cancer cells often overexpress PD-L1, so blocking the immune attack against themselves. This has provided a strong rationale for the development of drugs targeting the PD-1 pathway. Indeed, drugs blocking the binding of PD-L1 to its receptor, such as nivolumab and pembrolizumab, enhance immunity against a wide variety of cancers, including NSCLC [24]. Nivolumab was initially FDA-approved strictly for lung SCCs and regardless of PD-L1 expression analysis, thus becoming the second-line treatment of choice after failure of first-line platinum-based therapeutic regimes: a major breakthrough in the field of SCC therapy after years of quiet $[8,25]$. Later on, nivolumab has been approved also for lung adenocarcinoma patients with progression on or after platinum-based chemotherapy; however, patients with EGFR or ALK-1 genomic aberrations should also have had disease progression on FDA-approved therapy for these aberrations prior to receiving nivolumab $[8,26]$. Pembrolizumab is indicated for the first-line treatment of any histological type of metastatic NSCLC if the tumor is highly positive for PD-L1 expression and negative for EGFR and ALK-1 genetic aberrations $[8,27,28]$. In the second-line, pembrolizumab is indicated for the treatment of even low PD-L1 expressing NSCLCs that have progressed on or after platinum-based chemotherapy. However, again, patients with EGFR or ALK-1 genomic aberrations should have shown disease progression on FDA-approved therapy for these aberrations prior to receiving pembrolizumab [8]. Atezolizumab, another PD-L1 blocking antibody, has been approved for the treatment of patients with metastatic NSCLC whose disease progressed during or following platinum-containing chemotherapy. Also in this case, patients with EGFR or ALK genomic tumor mutations should have had disease progression on FDA-approved therapy for these aberrations prior to receiving atezolizumab [8,29]. Of note, until now, nivolumab, pembrolizumab, and atezolizumab have received FDA approval as single agents. Many clinical trials are ongoing to address the anti-PD-L1/PD-1 therapy efficacy in combination with other therapies and the results are eagerly awaited [30]. 
Table 2. Immunotherapy for NSCLCs.

\begin{tabular}{ccc}
\hline Tumor Characteristics & FDA Approved Drug \\
\hline $\begin{array}{c}\text { High PD-L1 expression } \\
\text { Absence of EGFR or ALK-1 aberrations }\end{array}$ & First Line Therapy & Pembrolizumab [8,27,28] \\
\hline $\begin{array}{c}\text { Low PD-L1 expression } \\
\text { Disease progression on FDA-approved therapy }\end{array}$ & Second Line Therapy & Pembrolizumab [8,27,28] \\
\hline Disease progression on FDA-approved therapy & Second Line Therapy & $\begin{array}{c}\text { Nivolumab }[8,25,26] \\
\text { Atezolizumab }[8,29]\end{array}$ \\
\hline
\end{tabular}

\subsection{New Therapeutic Perspectives for Lung Cancers}

As reviewed above, in the very last few years, several new drugs have been approved for the treatment of NSCLCs. The bad news is that we are now witnessing that, after dramatic initial responses, the long-term effects of these drugs are almost always hampered by complications, such as hyperprogression upon anti-PD-L1/PD-1 therapy, or by acquired resistance [31-33]. The good news is that we have learnt that the time gap between bench to bedside is getting shorter, so the search for novel genetic aberrations that can be exploited to further personalize therapy warrants investigation.

We have recently demonstrated that in about $30 \%$ of NSCLC the tumor suppressor protein CCDC6 is expressed at low levels. Remarkably, CCDC6 low levels indicate poor prognosis, correlating positively with the presence of lymph node metastasis and negatively with disease free survival [34]. CCDC6, a negative regulator of CREB1 transcriptional activity and a substrate of ATM, sustains DNA damage checkpoints in response to genotoxic events, CCDC6 loss affecting the repair of the DNA double-strand breaks (DSBs) [35-39]. Accordingly, lung cancer cells expressing low levels of CCDC6 have severe defects in the homologous recombination (HR) DNA repair pathway induced by DSBs [34]. For the treatment of ovarian cancers, bearing HR DNA repair defects because of BRCA1/2 mutations, the FDA has approved olaparib, an inhibitor of the repair enzyme Poly(ADP-ribose) polymerase (PARP) $[8,40,41]$. Inhibition of PARP causes a collapse in the base excision repair (BER) pathway and results in the accumulation of single strand breaks that end up in DSBs upon DNA replication. In healthy cells, PARP inhibition is not of great consequence because of effective DSB repair. However, in the context of BRCA-mutated cancers with compromised HR repair, the BER pathway failure and, in turn, the accumulations of DSBs caused by the PARP inhibitor kill tumor cells [42]. Thus, given the defects in HR repair caused by CCDC6 loss, we hypothesized that CCDC6 defective lung cancer cells should have been sensitive to treatment with olaparib. Indeed, we have demonstrated that low levels of CCDC6 protein increase lung cancer cells' sensitivity to the sole olaparib treatment; moreover, olaparib synergizes with cisplatinum in killing cells [34]. Thus, our data suggest that, in NSCLCs, expressing low levels of CCDC6 the addition of olaparib to first-line platinum-based chemotherapy can be beneficial. However, as discussed above, CCDC6 protein levels are downregulated in $30 \%$ of NSCLCs. For the tumors that express normal levels of the protein, we propose a different therapeutic approach. CCDC6 protein levels are finely regulated by the E3 ubiquitin ligase Fbxw7, that addresses CCDC6 to proteasome degradation, and by the de-ubiquitinase Usp7 that, on the contrary, stabilizes it [43]. Thus, we reasoned that P5091, an Usp7 inhibitor, lowering CCDC6 levels, should sensitize even lung cancer cells that express normal level of the protein to olaparib. Indeed, this is the case. Remarkably, P5091 synergizes with olaparib and cisplatinum also in cells derived from neuroendocrine small-cell lung cancers (SCLCs) [44]. These results suggest a new therapeutic option also for SCLCs that have been excluded by the recent advances in target therapies and are, thus, still treated only with platinum-based chemotherapy, with quite dismal results.

CCDC6 was first identified as a gene frequently rearranged with the RET tyrosine kinase gene in papillary thyroid cancers [45]. In detail, as a consequence of the chromosomal rearrangement, the first 101 amino acids of the CCDC6 protein are fused to the RET tyrosine kinase domain that results constitutively active [46]. Albeit at low frequency, CCDC6 has been found rearranged with the tyrosine kinase RET also in NSCLCs [47]. In a phase II clinical trial vandetanib, a novel tyrosine 
kinase inhibitor of RET, showed clinical antitumor activity and a manageable safety profile in patients with advanced RET-rearranged NSCLCs [48]. In cells bearing CCDC6/RET rearrangements, CCDC6 function is completely lost because the CCDC6/RET chimeric protein acts as a dominant negative on the wild type CCDC6 protein codified by the non-rearranged allele [46]. Thus, the hypothesis that the functional loss of CCDC6 should sensitize also the RET-rearranged NSCLCs to olaparib-alone or in combination with vandetanib-is a promising starting point for further tests in preclinical and clinical settings.

\section{Conclusions}

In the last few years, many new target drugs have been approved by the FDA for the treatment of NSCLCs. Drugs targeting ALK, ROS, and the EGF and VEGF pathways have been particularly beneficial for patients with non-squamous NSCLCs. The very recent approval of drugs targeting the PD-L1/PD-1 pathway has been a groundbreaking advancement especially for the treatment of squamous NSCLCs. However, we have learnt that - after dramatic initial responses-the long-term effects of the target cancer therapies are limited mainly by acquired resistance. So, searching for new therapeutic options always warrants efforts. On the basis of the results obtained in NSCLC and SCLC-derived cell lines and in tumor samples, we envision CCDC6 as a biomarker for a more personalized lung cancer therapy. If the tumor expresses low levels of the protein, we expect it to respond to olaparib; if it expresses high levels of the protein the sensitivity to olaparib can be restored by the addition of the Usp7 inhibitor. Olaparib administration can be tested alone or in combination with classical chemotherapeutical drugs, such as cisplatinum, or with new target drugs, such as vandetanib in cases of CCDC6/RET-rearranged NSCLCs where the function of CCDC6 is lost.

Acknowledgments: This work was supported by the Associazione Italiana Ricerca sul Cancro (AIRC n. 4952 to AC), by POR Campania FSE 2007/2013 "CREME Campania Research in Experimental Medicine" to CNR-IEOS-UOS Napoli, and by the "Ministero dell'Istruzione, dell'Università e della Ricerca" (MIUR) (PRIN 2009T5NKTB_002 to AC). Francesco Morra acknowledges the "Programma Garanzia Giovani" Regione Campania DGR 117/2014, PIP.

Conflicts of Interest: The authors declare no conflict of interest.

\section{Abbreviations}

$\begin{array}{ll}\text { CCDC6 } & \text { Coiled Coil Domain Containing protein } 6 \\ \text { NSCLC } & \text { Non-Small-Cell Lung Cancer } \\ \text { FDA } & \text { Food and Drug Administration } \\ \text { SCC } & \text { Squamous Cell Carcinoma } \\ \text { EGFR } & \text { Epidermal Growth Factor Receptor } \\ \text { VEGF } & \text { Vascular Endothelial Growth Factor } \\ \text { PD-1 } & \text { Programmed cell-Death-1 receptor } \\ \text { PD-L1 } & \text { Programmed cell Death-Ligand 1 } \\ \text { DSB } & \text { Double-Strand Break } \\ \text { HR } & \text { Homologous Recombination } \\ \text { PARP } & \text { Poly(ADP-Ribose) Polymerase } \\ \text { BER } & \text { Base Excision Repair } \\ \text { SCLC } & \text { Small-Cell Lung Cancer }\end{array}$

\section{References}

1. Siegel, R.L.; Miller, K.D.; Jemal, A. Cancer Statistics, 2017. CA Cancer J. Clin. 2017, 67, 7-30. [CrossRef] [PubMed]

2. Lackey, A.; Donington, J.S. Surgical management of lung cancer. Semin. Interv. Radiol. 2013, 30, 133-140. [CrossRef] [PubMed] 
3. Vansteenkiste, J.; De Ruysscher, D.; Eberhardt, W.E.; Lim, E.; Senan, S.; Felip, E.; Peters, S.; ESMO Guidelines Working Group. Early and locally advanced non-small-cell lung cancer (NSCLC): ESMO clinical practice guidelines for diagnosis, treatment and follow-up. Ann. Oncol. 2013, 24, 89-98. [CrossRef] [PubMed]

4. Lim, E.; Harris, G.; Patel, A.; Adachi, I.; Edmonds, L.; Song, F. Preoperative versus postoperative chemotherapy in patients with resectable non-small cell lung cancer: Systematic review and indirect comparison meta-analysis of randomized trials. J. Thorac. Oncol. 2009, 4, 1380-1388. [CrossRef] [PubMed]

5. Albain, K.S.; Swann, R.S.; Rusch, V.W.; Turrisi, A.T., 3rd; Shepherd, F.A.; Smith, C.; Chen, Y.; Livingston, R.B.; Feins, R.H.; Gandara, D.R.; et al. Radiotherapy plus chemotherapy with or without surgical resection for stage III non-small-cell lung cancer: A phase III randomised controlled trial. Lancet 2009, 374, 379-386. [CrossRef]

6. Travis, W.D.; Brambilla, E.; Nicholson, A.G.; Yatabe, Y.; Austin, J.H.; Beasley, M.B.; Chirieac, L.R.; Dacic, S.; Duhig, E.; Flieder, D.B.; et al. The 2015 World Health Organization classification of lung tumors: Impact of genetic, clinical, and radiologic advances since the 2004 classification. J. Thorac. Oncol. 2015, 10, 1243-1260. [CrossRef] [PubMed]

7. Solomon, B.J.; Mok, T.; Kim, D.W.; Wu, Y.L.; Nakagawa, K.; Mekhail, T.; Felip, E.; Cappuzzo, F.; Paolini, J.; Usari, T.; et al. PROFILE 1014 investigators. First-line crizotinib versus chemotherapy in ALK-positive lung cancer. N. Engl. J. Med. 2014, 371, 2167-2177. [CrossRef] [PubMed]

8. Drugs@FDA: FDA Approved Drug Products. Available online: http://www.accessdata.fda.gov/scripts / cder/daf/index.cfm (accessed on 8 May 2017).

9. Shaw, A.T.; Ou, S.H.; Bang, Y.J.; Camidge, D.R.; Solomon, B.J.; Salgia, R.; Riely, G.J.; Varella-Garcia, M.; Shapiro, G.I.; Costa, D.B.; et al. Crizotinib in ROS1-rearranged non-small-cell lung cancer. N. Engl. J. Med. 2014, 371, 1963-1971. [CrossRef] [PubMed]

10. Yang, J.C.; Wu, Y.L.; Schuler, M.; Sebastian, M.; Popat, S.; Yamamoto, N.; Zhou, C.; Hu, C.P.; O’Byrne, K.; Feng, J.; et al. Afatinib versus cisplatin-based chemotherapy for EGFR mutation-positive lung adenocarcinoma (LUX-Lung 3 and LUX-Lung 6): Analysis of overall survival data from two randomised, phase 3 trials. Lancet Oncol. 2015, 16, 141-151. [CrossRef]

11. Soria, J.C.; Mauguen, A.; Reck, M.; Sandler, A.B.; Saijo, N.; Johnson, D.H.; Burcoveanu, D.; Fukuoka, M.; Besse, B.; Pignon, J.P.; Meta-Analysis of Bevacizumab in Advanced NSCLC Collaborative Group. Systematic review and meta-analysis of randomised, phase II/III trials adding bevacizumab to platinum-based chemotherapy as first-line treatment in patients with advanced non-small-cell lung cancer. Ann. Oncol. 2013, 24, 20-30. [CrossRef] [PubMed]

12. Kim, D.W.; Mehra, R.; Tan, D.S.; Felip, E.; Chow, L.Q.; Camidge, D.R.; Vansteenkiste, J.; Sharma, S.; De Pas, T.; Riely, G.J.; et al. Activity and safety of ceritinib in patients with ALK-rearranged non-small-cell lung cancer (ASCEND-1): Updated results from the multicentre, open-label, phase 1 trial. Lancet Oncol. 2016, 17, 452-463. [CrossRef]

13. Ou, S.H.; Ahn, J.S.; De Petris, L.; Govindan, R.; Yang, J.C.; Hughes, B.; Lena, H.; Moro-Sibilot, D.; Bearz, A.; Ramirez, S.V.; et al. Alectinib in crizotinib-refractory ALK-rearranged non-small-cell lung cancer: A phase II global study. J. Clin. Oncol. 2016, 34, 661-668. [CrossRef] [PubMed]

14. Kim, D.W.; Tiseo, M.; Ahn, M.J.; Reckamp, K.L.; Hansen, K.H.; Kim, S.W.; Huber, R.M.; West, H.L.; Groen, H.J.M.; Hochmair, M.J.; et al. Brigatinib in patients with crizotinib-refractory anaplastic lymphoma kinase-positive non-small-cell lung cancer: A randomized, multicenter phase II trial. J. Clin. Oncol. in press. [CrossRef] [PubMed]

15. Jänne, P.A.; Yang, J.C.; Kim, D.W.; Planchard, D.; Ohe, Y.; Ramalingam, S.S.; Ahn, M.J.; Kim, S.W.; Su, W.C.; Horn, L.; et al. AZD9291 in EGFR inhibitor-resistant non-small-cell lung cancer. N. Engl. J. Med. 2015, 372, 1689-1699.

16. Garon, E.B.; Ciuleanu, T.E.; Arrieta, O.; Prabhash, K.; Syrigos, K.N.; Goksel, T.; Park, K.; Gorbunova, V.; Kowalyszyn, R.D.; Pikiel, J.; et al. Ramucirumab plus docetaxel versus placebo plus docetaxel for second-line treatment of stage IV non-small-cell lung cancer after disease progression on platinum-based therapy (REVEL): A multicentre, double-blind, randomised phase 3 trial. Lancet 2014, 384, 665-673. [CrossRef]

17. Soda, M.; Choi, Y.L.; Enomoto, M.; Takada, S.; Yamashita, Y.; Ishikawa, S.; Fujiwara, S.; Watanabe, H.; Kurashina, K.; Hatanaka, H.; et al. Identification of the transforming EML4-ALK fusion gene in non-small-cell lung cancer. Nature 2007, 448, 561-566. [CrossRef] [PubMed] 
18. Rikova, K.; Guo, A.; Zeng, Q.; Possemato, A.; Yu, J.; Haack, H.; Nardone, J.; Lee, K.; Reeves, C.; Li, Y.; et al. Global survey of phosphotyrosine signaling identifies oncogenic kinases in lung cancer. Cell 2007, 131, 1190-1203. [CrossRef] [PubMed]

19. Pao, W.; Miller, V.A.; Politi, K.A.; Riely, G.J.; Somwar, R.; Zakowski, M.F.; Kris, M.G.; Varmus, H. Acquired resistance of lung adenocarcinomas to gefitinib or erlotinib is associated with a second mutation in the EGFR kinase domain. PLoS Med. 2005, 2, e73. [CrossRef] [PubMed]

20. Martin, P.; Leighl, N.B.; Tsao, M.S.; Shepherd, F.A. KRAS mutations as prognostic and predictive markers in non-small cell lung cancer. J. Thorac. Oncol. 2013, 8, 530-542. [CrossRef] [PubMed]

21. Johnson, D.H.; Fehrenbacher, L.; Novotny, W.F.; Herbst, R.S.; Nemunaitis, J.J.; Jablons, D.M.; Langer, C.J.; DeVore, R.F., 3rd; Gaudreault, J.; Damico, L.A.; et al. Randomized phase II trial comparing bevacizumab plus carboplatin and paclitaxel with carboplatin and paclitaxel alone in previously untreated locally advanced or metastatic non-small-cell lung cancer. J. Clin. Oncol. 2004, 22, 2184-2191. [CrossRef] [PubMed]

22. Pikor, L.A.; Ramnarine, V.R.; Lam, S.; Lam, W.L. Genetic alterations defining NSCLC subtypes and their therapeutic implications. Lung Cancer 2013, 82, 179-189. [CrossRef] [PubMed]

23. Yao, S.; Chen, L. PD-1 as an immune modulatory receptor. Cancer J. 2014, 20, 262-264. [CrossRef] [PubMed]

24. Catakovic, K.; Klieser, E.; Neureiter, D.; Geisberger, R. T cell exhaustion: From pathophysiological basics to tumor immunotherapy. Cell Commun. Signal. 2017, 15, 1. [CrossRef] [PubMed]

25. Brahmer, J.; Reckamp, K.L.; Baas, P.; Crinò, L.; Eberhardt, W.E.; Poddubskaya, E.; Antonia, S.; Pluzanski, A.; Vokes, E.E.; Holgado, E.; et al. Nivolumab versus docetaxel in advanced squamous-cell non-small-cell lung cancer. N. Engl. J. Med. 2015, 373, 123-135. [CrossRef] [PubMed]

26. Borghaei, H.; Paz-Ares, L.; Horn, L.; Spigel, D.R.; Steins, M.; Ready, N.E.; Chow, L.Q.; Vokes, E.E.; Felip, E.; Holgado, E.; et al. Nivolumab versus docetaxel in advanced nonsquamous non-small-cell lung cancer. N. Engl. J. Med. 2015, 373, 1627-1639. [CrossRef] [PubMed]

27. Herbst, R.S.; Baas, P.; Kim, D.W.; Felip, E.; Pérez-Gracia, J.L.; Han, J.Y.; Molina, J.; Kim, J.H.; Arvis, C.D.; Ahn, M.J.; et al. Pembrolizumab versus docetaxel for previously treated, PD-L1-positive, advanced non-small-cell lung cancer (KEYNOTE-010): A randomised controlled trial. Lancet 2016, 387, 1540-1550. [CrossRef]

28. Reck, M.; Rodríguez-Abreu, D.; Robinson, A.G.; Hui, R.; Csőszi, T.; Fülöp, A.; Gottfried, M.; Peled, N.; Tafreshi, A.; Cuffe, S.; et al. Pembrolizumab versus chemotherapy for PD-L1-positive non-small-cell lung cancer. N. Engl. J. Med. 2016, 375, 1823-1833. [CrossRef] [PubMed]

29. Rittmeyer, A.; Barlesi, F.; Waterkamp, D.; Park, K.; Ciardiello, F.; von Pawel, J.; Gadgeel, S.M.; Hida, T.; Kowalski, D.M.; Dols, M.C.; et al. Atezolizumab versus docetaxel in patients with previously treated non-small-cell lung cancer (OAK): A phase 3, open-label, multicentre randomised controlled trial. Lancet 2017, 389, 255-265. [CrossRef]

30. Scarpace, S.L. Metastatic squamous cell non-small-cell lung cancer (NSCLC): Disrupting the drug treatment paradigm with immunotherapies. Drugs Context 2015, 4, 212289. [CrossRef] [PubMed]

31. Champiat, S.; Dercle, L.; Ammari, S.; Massard, C.; Hollebecque, A.; Postel-Vinay, S.; Chaput, N.; Eggermont, A.; Marabelle, A.; Soria, J.C.; et al. Hyperprogressive disease is a new pattern of progression in cancer patients treated by anti-PD-1/PD-L1. Clin. Cancer Res. 2016, 23, 1920-1928. [CrossRef] [PubMed]

32. Bansal, P.; Osman, D.; Gan, G.N.; Simon, G.R.; Boumber, Y. Recent advances in targetable therapetics in metastatic non-squamous NSCLC. Front. Oncol. 2016, 6, 112. [PubMed]

33. Ramos, P.; Bentires-Alj, M. Mechanism-based cancer therapy: Resistance to therapy, therapy for resistance. Oncogene 2015, 34, 3617-3626. [CrossRef] [PubMed]

34. Morra, F.; Luise, C.; Visconti, R.; Staibano, S.; Merolla, F.; Ilardi, G.; Guggino, G.; Paladino, S.; Sarnataro, D.; Franco, R.; et al. New therapeutic perspectives in CCDC6 deficient lung cancer cells. Int. J. Cancer 2015, 136, 2146-2157. [CrossRef] [PubMed]

35. Leone, V.; Mansueto, G.; Pierantoni, G.M.; Tornincasa, M.; Merolla, M.; Cerrato, A.; Santoro, M.; Grieco, M.; Celetti, A.; Fusco, A. CCDC6 represses CREB1 activity by recruiting histone deacetylase I and PP1. Oncogene 2010, 29, 4341-4351. [CrossRef] [PubMed]

36. Luise, C.; Merolla, F.; Leone, V.; Paladino, S.; Sarnataro, D.; Fusco, A.; Celetti, A. Identification of sumoylation sites in CCDC6, the first identified RET partner gene, uncover a mode of regulating CCDC6 function on CREB1 transcriptional activity. PLoS ONE 2012, 7, 1-11. [CrossRef] [PubMed] 
37. Leone, V.; Langella, C.; Esposito, F.; Arra, C.; Palma, G.; Paciello, O.; Merolla, F.; De Biase, D.; Papparella, S.; Celetti, A.; et al. Ccdc6 knock-in mice develop thyroid hyperplasia associated to an enhanced CREB1 activity. Oncotarget 2015, 6, 15628-15638. [CrossRef] [PubMed]

38. Merolla, F.; Pentimalli, F.; Pacelli, R.; Vecchio, G.; Fusco, A.; Grieco, M.; Celetti, A. Involvement of H4(D10S170) protein in ATM-dependent response to DNA damage. Oncogene 2007, 26, 6167-6175. [CrossRef] [PubMed]

39. Merolla, F.; Luise, C.; Muller, M.T.; Pacelli, R.; Fusco, A.; Celetti, A. Loss of CCDC6, the first identified RET partner gene, affects pH2AX S139 levels and accelerates mitotic entry upon DNA damage. PLoS ONE. 2012, 7, e36177. [CrossRef] [PubMed]

40. Tutt, A.; Robson, M.; Garber, J.E.; Domchek, S.M.; Audeh, M.W.; Weitzel, J.N.; Friedlander, M.; Arun, B.; Loman, N.; Schmutzler, R.K.; et al. Oral poly(ADP-ribose) polymerase inhibitor olaparib in patients with BRCA1 or BRCA2 mutations and advanced breast cancer: A proof-of-concept trial. Lancet 2010, 376, 235-244. [CrossRef]

41. Audeh, M.W.; Carmichael, J.; Penson, R.T.; Friedlander, M.; Powell, B.; Bell-McGuinn, K.M.; Scott, C.; Weitzel, J.N.; Oaknin, A.; Loman, N.; et al. Oral poly(ADP-ribose) polymerase inhibitor olaparib in patients with BRCA1 or BRCA2 mutations and recurrent ovarian cancer: A proof-of-concept trial. Lancet 2010, 376, 245-251. [CrossRef]

42. Cerrato, A.; Morra, F.; Celetti, A. Use of poly ADP-ribose polymerase [PARP] inhibitors in cancer cells bearing DDR defects: The rationale for their inclusion in the clinic. J. Exp. Clin. Cancer Res. 2016, 35, 179. [CrossRef] [PubMed]

43. Morra, F.; Luise, C.; Merolla, F.; Poser, I.; Visconti, R.; Ilardi, G.; Paladino, S.; Inuzuka, H.; Guggino, G.; Monaco, R.; et al. FBXW7 and USP7 regulate CCDC6 turnover during the cell cycle and affect cancer drugs susceptibility in NSCLC. Oncotarget 2015, 6, 12697-12709. [CrossRef] [PubMed]

44. Malapelle, U.; Morra, F.; Ilardi, G.; Visconti, R.; Merolla, F.; Cerrato, A.; Napolitano, V.; Monaco, R.; Guggino, G.; Monaco, G.; et al. USP7 inhibitors, downregulating CCDC6, sensitize lung neuroendocrine cancer cells to PARP-inhibitor drugs. Lung Cancer 2017, 107, 41-49. [CrossRef] [PubMed]

45. Grieco, M.; Santoro, M.; Berlingieri, M.T.; Melillo, R.M.; Donghi, R.; Bongarzone, I.; Pierotti, M.A.; Della Porta, G.; Fusco, A.; Vecchio, G. PTC is a novel rearranged form of the ret proto-oncogene and is frequently detected in vivo in human thyroid papillary carcinomas. Cell 1990, 60, 557-563. [CrossRef]

46. Celetti, A.; Cerrato, A.; Merolla, F.; Vitagliano, D.; Vecchio, G.; Grieco, M. H4(D10S170), a gene frequently rearranged with RET in papillary thyroid carcinomas: Functional characterization. Oncogene 2004, 23, 109-121. [CrossRef] [PubMed]

47. Takeuchi, K.; Soda, M.; Togashi, Y.; Suzuki, R.; Sakata, S.; Hatano, S.; Asaka, R.; Hamanaka, W.; Ninomiya, H.; Uehara, H.; et al. RET, ROS1 and ALK fusions in lung cancer. Nat. Med. 2012, 18, 378-381. [CrossRef] [PubMed]

48. Yoh, K.; Seto, T.; Satouchi, M.; Nishio, M.; Yamamoto, N.; Murakami, H.; Nogami, N.; Matsumoto, S.; Kohno, T.; Tsuta, K.; et al. Vandetanib in patients with previously treated RET-rearranged advanced non-small-cell lung cancer (LURET): An open-label, multicentre phase 2 trial. Lancet Respir. Med. 2017, 5, 42-50. [CrossRef]

(c) 2017 by the authors. Licensee MDPI, Basel, Switzerland. This article is an open access article distributed under the terms and conditions of the Creative Commons Attribution (CC BY) license (http://creativecommons.org/licenses/by/4.0/). 